\title{
MEMBELAJARKAN BAHASA INDONESIA UNTUK GENERASI DIGITAL DI SEKOLAH DASAR
}

\author{
Ferril Irham Muzaki \\ KSDP, FIP,Universitas Negeri Malang Jl. Semarang No.5 Malang \\ email:ferril.irham.fip@um.ac.id
}

\begin{abstract}
Abstrak: Perkembangan teknologi digital telah memberikan berbagai macam tantangan bagi proses pendidikan di sekolah dasar. Tantangan untuk proses pembelajaran ini semakin nyata seiring dengan perkembangan generasi digital (Digital Native). Generasi yang terlahir dalam kubangan digital memiliki tantangan belajar dan peluang yang berbeda dibanding dengan generasi sebelumnya. Kemampuan dan ketersediaan teknologi bisa difasilitasi oleh guru untuk mengembangkan keterampilan mereka dalam menemukan infomasi.
\end{abstract}

Kata kunci: Digital native, guru sebagai fasilitator, teknologi informasi dan komunikasi

Perkembangan teknologi komunikasi dan informasi yang semakin berkembang cepat pada dewasa ini telah melahirkan generasi digital (digital native). Prensky (2001:2) menyatakan bahwa generasi ini merupakan generasi yang terbiasa untuk memperoleh informasi melalui perangkat digital. Selain itu generasi digital juga sudah memiliki kemampuan untuk mengakses pada saat yang bersamaan menyebarkan informasi digital melalui perangkat yang mereka gunakan, baik dimiliki sendiri ataupun dengan cara yang lain. Generasi digital merupakan generasi yang berbeda jika dibandingkan dengan generasi sebelumnya. Generasi ini memiliki peluang untuk belajar dan memperoleh secara mandiri.

Kemandirian untuk memperoleh informasi bagi generasi ini perlu diajarkan sejak berada di bangku sekolah dasar. Prensky (2001:23) menyatakan bahwa dengan mengajarkan kemandirian dalam memperoleh informasi seorang pebelajar generasi digital memiliki kemampuan yang khas untuk mengembangkan diri. Pembelajaran untuk generasi digital memerlukan penugasan-penugasan, yakni mencari berbagai macam informasi yang bisa diperoleh secara online. Penugasan-penugasan untuk mencari informasi secara online juga memerlukan kendali dari pihak guru. Kendali tersebut bisa diwujudkan dalam bentuk kendali waktu dan arus informasi. Dengan demikian penugasan-penugasan untuk memperoleh informasi secara online menjadi semakin dominan.

Generasi digital terlahir sebagai imbas dari teknologi komunikasi dan informasi yang memberikan pajanan bagi mereka sejak mereka lahir. Generasi yang terlahir pada tahun 2000 sudah terbiasa menggunakan televisi, seiring dengan perkembangan teknologi maka ponsel dan internet sudah lazim dijumpai. Persewaan untuk komunikasi dan rekresasi berbasis online mulai lazim dijumpai di desa-desa pelosok Jawa Timur. Penggunaan perangkat modem yang bersifat mobile, mudah untuk ditancapkan di laptop, tersedia dengan akses yang semakin mendekat jejaring yang menggunakan kabel (fixed line).

Seiring dengan perkembangan piranti transfer data diprediksi generasi digital akan semakin banyak lahir bahkan hingga ke pelosok termasuk distribusi sinyal. Pada 
era 2000, perangkat telepon seluler menjadi barang mewah yang pemakainya hanya di kota-kota yang terjangkau akses teknologi. Pada tahun 2014 sudah lazim dijumpai bedak penjualan pulsa di desa-desa di jawa Timur. Maknanya pengguna piranti komunikasi seluler sudah merambah hingga pelosok jawa timur. Saat ini di tahun 2015 sedang dirintis perangkat balon udara yang mampu mendistribusikan sinyal wi-fi (https://www. google.com/loon/). Jika riset ini membuahkan hasil maka sinyal untuk komunikasi internet bisa dipasok hingga daerah yang saat ini tidak terjangkau oleh sinyal.

Untuk memperoleh perangkat komunikasi seluler dan digital pada saat ini semakin murah. Sebagai contoh pada tahun 2004 untuk membeli kartu perdana diperlukan biaya 750.000. Pada saat artikel ini ditulis harga untuk kartu perdana mencapai 3000 rupiah, bahkan di beberapa pusat perbelanjaan kartu perdana dibagikan secara cuma-cuma.

Sebagai pendidik sudah selayaknya tantangan untuk membelajarkan generasi digital ini menjadi sebuah keniscayaan. Guru sekolah dasar sudah mesti memiliki dasar-dasar kemampuan untuk menguasai perangkat digital berikut cara menggunakannya untuk proses pembelajaran. Keberadaan piranti digital dalam mendistribusikan informasi menjadi sebuah keharusan, dikarenakan keberadaan piranti digital. Guru sekolah dasar juga sudah mesti mempersiapkan kemungkinan tergantikannya perangkat konvensional menjadi pembelajaran digital (E-Book) yang lebih murah dan mudah untuk didistribusikan. Kemahiran untuk mengakses informasi serta menyesuaikan tema-tema yang aktual untuk diintegerasikan dalam pembelajaran kelas menjadi semakin diperlukan.

Piranti untuk belajar dengan cara digital tidak hanya berasal dari situs wiki saja, melainkan dari ensklopedia digital dan berbagai macam sumber belajar lainnya. Contohnya adalah CD/DVD room yang berisi informasi untuk proses pembelajaran. Informasi yang disebarkan berbasis komunitas virtual seperti mailing list, grup facebook/whats'up dan berbagai macam komunitas tuturan online (chatgroup) secara dominan. Film dan media dengar (Podcast) yang diekemas dalam bentuk file digital yang didistribusikan melalui flasdisk ataupun piranti external driver lainnya. Bukubuku yang bisa didapat melalui apps (aplikasi) yang tersedia di Android dan berbagai macam sistim operasi lainnya. Perangkat pembelajaran yang interaktif, tidak sekadar perangkat pembelajaran akan tetapi piranti pembelajaran yang memungkinkan interaksi jarak jauh antara guru dengan pebelajar melalui video conferences.

Tantangan untuk membelajarkan generasi digital di masa depan merupakan sebuah keharusan. Perisapan untuk membelajarkan generasi digital perlu dipersiapkan sejak dari awal yakni penyiapan guru yang melek piranti digital. Seorang guru dipersiapkan bukan hanya menggunakan melainkan memanfaatkan piranti digital untuk proses pembelajaran. Dalam artikel ini akan dikhususkan pada bahasa Indonesia dengan mempertimbangkan tema-tema lain seperti yang sesuai dengan pembelajar di SD yang bersifat tematik-integratif.

\section{Konsep Dasar}

Dalam bagian kajan pustaka akan dipaparkan tiga hal yang menjadi rujukan teori dalam artikel ini. Ketiga rujukan teori tersebut adalah (1) generasi digital, (2) teknologi dan belajar di abad digital, (3) tantangan membelajarkan generasi digital dan (3) pembelajaran berbasis perangkat digital.

\section{Generasi Digital}

Generasi digital merupakan generasi yang terlahir di tengah perangkat digital. Generasi ini memiliki gaya tersendiri dibanding generasi sebelumnya. Prensky (2001:3) menuturkan gaya belajar generasi digital ada beberapa yaitu (1) belajar dengan pajanan informasi sendiri, (2) memiliki kemampuan untuk mengakses informasi secara cepat, (3) memiliki keterampilan untuk mengolah informasi den- 
gan piranti digital yang mereka miliki dan (4) memiliki kemampuan untuk mempublikasikan informasi yang mereka dapatkan.

\section{Teknologi dan Belajar di Abad Digital}

Shah dan Abraham (2009:3) menuturkan dalam membelajarkan generasi yang memiliki kemampuan untuk akses informasi secara cepat beberapa hal yang perlu diperhatikan yaitu (1) kesesuaian tema pembelajaran, (2) kemampuan pebelajara untuk mengadaptasi teknologi, (3) keserasian informasi dengan dunia, dan (4) keterampilan guru untuk menyajikan informasi yang sesuai di kelas.

\section{Tantangan Pembelajaran Kedepan}

Pembelajaran untuk digital native memiliki peluang untuk diterapkan dengan dua pola. Pola pertama adalah pembelajaran berbasis tutorial. Yunus dan Suliman (2014:34) menuturkan pada periode tertentu dimana guru berfungsi sebagai tutor yang memandu proses pembelajaran. Pada tahap yang lain pebelajar belajar di rumah masing-masing menggunakan panduan perangkat digital.

Pembelajaran dengan pola kedua adalah pembelajaran yang berbasis teknologi informasi. Pebelajar belajar secara penuh di rumah. Tugas-tugas dikirim via surat elektronik serta pembelajaran dilakukan dengan interaksi via chat. Untuk melatih proses pembelajaran pada waktu-waktu tertentu pebelajar diajak berinteraksi di lingkungan dengan permainan.

\section{Pembelajaran Bahasa Indonesia di Abad Digital}

Kemampuan untuk berperan serta sekaligus aktif dalam proses pembelajaran di kelas menjadi semakin dominan seiring dengan laju perkembangan arus informasi yang ada di dalam proses interaksi kelas itu sendiri. Flores (2015:3) menyatakan dalam proses tersebut guru berusaha untuk meyampaikan pesan berupa materi pembelajaran sedangkan pebelajar menerima pesan dan mempelajari keterampilan yang diajarkan dalam proses kognitif mereka.

Di dalam kelas-kelas bahasa seorang guru mengejarkan kemampuan untuk bernalar dan pada saat yang bersamaan seorang guru juga mengajarkan untuk mengembangkan diri bagi pebelajar. Generasi-generasi ini perlu memiliki tantangan berupa mengembangkan jati diri mereka di tengah arus global yang semakin berat dan beragam.

\section{Pemanfaatan Media Internet untuk Pebelajar Digital Native Memanfaatkan Film Sebagai Sumber \\ Belajar Bahasa Indonesia}

Dalam kegiatan pembelajaran bahasa Indonesia di SD, sumber belajar tidak serta merta belajar dari buku teks. Sumber belajar bisa berasal dari berbagai macam sumber. Contohnya adalah memanfaatkan dialog dalam film. Kosakata yang ada dalam film-film dengan tema edukasi bisa dijadikan sebagai bahan untuk menyimak. Langkah-langkah untuk menfaatkan media tersebut contohnya (1) pebelajar diminta untuk mencatat katakata berimbuhan, dan (2) pebelajar diminta untuk menuliskan ulang kata-kata yang diperoleh dalam film melalui kalimat yang dikreasi sendiri.

\section{Latihan Mencari Informasi Berkenaan Kejadian Sosial}

Pembelajaran Bahasa bisa dikombinasikan dengan IPS (Ilmu Pengetahuan Sosial) dalam sebuah kesatuan tema. Guru kelas bisa menafaatkan internet sebagai wahana untuk: 1) berlatih untuk memperoleh informasi tentang pemerintahan di ibukota. 2) berlatih untuk mencari peta. 3) berlatih untuk melacak lokasi di peta buta. 4) berlatih menceritakan informasi.

Dengan demikian diharapkan proses pembelajaran menjadi semakin menyenangkan.

\section{Pembelajaran Bahasa Indonesia di Kelas Tinggi untuk Pebelajar Digital Native \\ - Berlatih Mencari Informasi di Dunia Digital}

Latihan untuk mencari informasi tentang pahlawan nasional dari internet merupakan 
salah satu kebermanfaatan media digital kepada anak-anak. Keberadaan media digital tersebut bisa dimanfaatkan untuk membuat laporan. Contoh dari kegiatan tersebut bagi peserta didik kelas rendah untuk tema IPS dan Bahasa antara lain: 1) mencari profil pahlawan nasional tersebut. 2) melacak sejarah perjuangan pahlawan nasional. 3) melacak nasib sejarah perjuangan. 4) menemukan hikmah di balik perjuangan pahlawan nasional

\section{- $\quad$ Latihan Mencari Teks Tentang Lingkungan Hidup}

Dalam pembelajaran berbasis tema di antara IPS, IPA, Matematika dan Bahasa Idonesia, proses pembelajaran memegang peranan utama. Pembelajaran untuk mencari teks bisa dilakukan dengan cara mencari tahu informasi berkenaan dengan: 1) bencana alam. 2) dampak banjir. 3) penanganan banjir. 4) pengolahan sampah.

\section{- Latihan Mengetik Terpandu oleh Guru}

Kebermanfatan media digital memiliki peluang untuk dimanfaatkan. Dalam konteks pemebelajaran bahasa Indonesia keterampilan untuk mengetik juga bisa diberi porsi disamping keterampilan untuk menulis menggunakan tangan. Elemen-elemen yang bisa dimasukkan dalam latihan tersebut antara lain: 1) menyimak kosa-kata. 2) mendengarkan dikte. 3) saling mendikte secara cepat. 4) berlatih untuk mengetik teks sederhana

\section{- Latihan Menulis Teks Sederhana}

Dalam proses pembelajaran di sekolah pada tingkat kelas rendah, pebelajar bisa diajak untuk mulai belajar mengetik. Mengetik dalam konteks ini bisa dilakukan dengan mengajarkan kegiatan berupa: 1) saling membetulkan ejaan antar teman. 2) mengetik cerita perjalan dari rumah ke sekolah. 3) mengetik deskripsi kelas. 4) menulis karangan sederhana

\section{- Berlatih untuk Menemukan Cerita Pendek}

Berlatih untuk menemukan informasi dalam dunia digital menjadi keterampilan yang memegang peranan utama. Salah satu contoh kegiatan tersebut adalah mencari cerita pendek. Pebelajar diajak untuk mencari sebuah cerita pendek ataupun dongeng kemudian diminta untuk melakukan beberapa hal yakni: 1) menemukan tokoh utama. 2) menuliskan latar peristiwa. 3) menuliskan cerita secara runtut. 4) menuliskan pesan moral

\section{- Berlatih Tuturan Ketika Berdiskusi \\ (Chat) Via Dunia Maya}

Melatih tuturan via dunia maya menjadi salah satu prioritas dalam proses pembelajaran. Pebelajar perlu diperkenalkan dengan dunia maya (web) yang sesuai dengan kegiatan mereka. Diharapkan pebelajar memiliki kemampuan untuk beradaptasi dengan dunia maya. Kegiatan-kegiatan tersebut bisa diwujudkan antara lain: 1) belajar untuk membuat akun surat elektronik. 2) belajar untuk mengirim e-mail. 3) belajar berdiskusi via chatbox ataupun e-mail tentang topik lingkngan. 4) belajar berdiskusi tntang topik-topik lain yang sesuai dengan tema.

\section{- Berlatih untuk Menemukan Berita}

Dengan panduan guru, pebelajar diajak untuk menemukan berbagai macam berita. Untuk menemukan berita pebelajar diperkenalkan dengan fitur-fitur internet seperti: 1) blog dan mikroblog. 2) web berita. 3) informasi dari situs berita bereputasi seperti kompas.com, detik.com, jpnn.com dan liputan6. com.

\section{Simpulan}

Pembelajaran untuk generasi digital erat kaitannya dengan kemampuan untuk berdiskusi antara pebelajar. Proses untuk belajar dalam dunia internet memegang peranan penting dalam proses pembelajaran, mempersiapkan gerasi digital untuk bisa beradaptasi di dunia digital.

Untuk penugasan-penugasan yang melibatkan internet dan dunia maya (surfing on web), pebelajar bisa diminta untuk didampingi orang tua jika di rumah. Pebelajar dan orang tua bisa diminta untuk mengisi chek- 
list yang ditandatangai oleh orang tua. Pada akhirnya keamanan untuk pebelajar menjadi terjaga mengingat tidak semua situs internet cocok untuk pebelajar muda.

Dengan demikian pembelajaran berbasis web diharapkan mampu untuk dijarakna dalam proses pembelajaran dikelas. Pembelajaran ini ditujukan untuk mempermudah pebelajar agar tidak gagap teknologi serta mampu menyesuaikan diri dan memanfaatkan berbagai macam perangkat digital yang ada untuk belajar.

\section{DAFTAR RUJUKAN}

Loon for All - Project Loon - Google. (2013). Retrieved from https://www.google.com/ loon/, diakses tanggal 4 November 2015. Online Learning and Teaching Resources. (2015). Retrieved November 8, 2015, from http://www.education.vic.gov.au/school/ teachers/support/pages/elearnresources. aspx

Prensky, M. (2001). Digital Natives, Digital Immigrants. On The Horizon, 9, 2-4. Retrieved from http://www.marcprensky. com/digital-native/, diakses tanggal 1 November 2015.

Shah, N., \& Abraham, S. (2009). Scope of Focus. In Digital Native with a Cause? (1st ed., p. 2). Retrieved from http:// cis-india.org/digital-natives/blog/dnrep. Diakes tanggal 30 Oktober 2015.

Yunus, M., \& Suliman, A. (2014). Information and Comunication Technology (ICT) Tools in Teacing and Learning Literature Component in Malaysian Secondary Schools. Assian Social Science, 10(7), 3-4. Retrieved from http://ccsenet.org/ journal/index.php/ass/article/view/35655, diakses tanggal 29 Oktober 2015. 